\title{
Assessment of the Potential Clastogenic/Aneugenic Risk of Casearia sylvestris Extract Using in Vivo Assays
}

\author{
Edson Luis Maistro ${ }^{1, *}$, Sergio Faloni de Andrade ${ }^{2}$ and \\ Marilane Aparecida Puras ${ }^{1}$ \\ ${ }^{1}$ Universidade Estadual Paulista, UNESP, Faculdade de Filosofia e Ciências, \\ Departamento de Fonoaudiologia, Marília, SP, Brazil. 17525-900. \\ ${ }^{2}$ Núcleo de Investigações Químico-Farmacêuticas (NIQFAR), Universidade \\ do Vale do Itajaí-UNIVALI, Itajaí, Santa Catarina, Brazil.
}

Received May 7, 2007; accepted October 19, 2007

\begin{abstract}
Summary Casearia sylvestris (Flacourtiaceae) is a plant which grows in wild and has been widely used in folk medicine. In this study, clastogenic/aneugenic properties of Casearia sylvestris crude ethanolic extract were evaluated using in vivo chromosomal aberrations (CAs) and micronucleus $(\mathrm{MN})$ assays in rodents. The animals were treated by gavage with 3 concentrations of the extract: 150,300 and $500 \mathrm{mg} / \mathrm{kg}$ body weight. Bone marrow cells from Wistar rats were collected $24 \mathrm{~h}$ after having been submitted to the MN and CAs test. Peripheral blood cells from Swiss mice were collected 48 and $72 \mathrm{~h}$ after having been submitted to the MN test. The results show that $C$. sylvestris extract does not induce a significant increase in mean values for micronucleated polychromatic erythrocytes (MNPCE) in Swiss mice and Wistar rats, or CAs in rat bone marrow cells, at the 3 tested doses, indicating that the extract showed no clastogenic/aneugenic effects on chromosomes of the rodent cells tested.
\end{abstract}

Key words Casearia sylvestris, Micronucleus test, Chromosome aberration, In vivo.

The use of plants for healing purposes is becoming increasingly popular, due to their benefits and freedom from side effects. However, most of the information available to consumers on various medicinal herbs does not have any support in scientific data. The use of many medicinal herbs is based simply on traditional folk use that has been perpetuated over generations. Since complex mixtures from plants with medical uses may contain toxic and genotoxic compounds, there has recently been growing interest in determining the genotoxicity of these compounds (Surh and Ferguson 2003).

Casearia sylvestris Swarts (Flacortinaceae) is very common in tropical America and the genus is represented in Brazil by 70 species. This plant is geographically distributed throughout Brazil and predominates from Amapá to Rio Grande do Sul (Le Cointe 1947, Lorenzi and Matos 2002) and is known in Brazil by popular names including Guaçatonga, Porangaba and Chá de Bugre. Its leaf extract is used in Brazilian folk medicine as an antiseptic and cicatrizant in skin diseases, and as a topical anesthetic (Hoehne 1939). Basile et al. (1990) refers preventive anti-ulcer activity of $C$. sylvestris leaf extract and also its low acute toxicity. Pre-clinical studies demonstrated that a crude extract of the fresh and dried leaves of $C$. sylvestris protects the mucosa of rat stomach and, according to the authors, these antiulcer activities may be due to the presence of volatile oils, tannins and triterpene-related compounds (Sertié et al. 2000). Esteves et al. (2005) also observe gastric antiulcer and anti-inflammatory activities of the essential oil from C. sylvestris.

Genotoxic studies evaluating Casearia sylvestris extracts are very scarce. Only one report has

* Corresponding author, e-mail: edson.maistro@marilia.unesp.br 
been performed, using in vitro single cell gel electrophoresis assay on Hepatoma Tissue Culture (HTC cells) in Rattus norvegicus and Chinese hamster V79 cells, and the results show that the crude ethanolic extract presents no genotoxic effects and no modified effect of inducing DNA damage by alkylating agents cyclophosphamide and methyl methanesulfonate on these cells (Maistro et al. 2004). Therefore, an attempt was made to evaluate the clastogenic/aneugenic risk of this crude ethanolic extract in rodent cells in vivo, using the micronucleus (MN) and chromosomal aberrations (CA) tests.

\section{Material and methods}

\section{Plant material}

The leaves of $C$. sylvestris were collected in the town of Alfenas, Minas Gerais, Brazil, and identified by Prof. Dr. José Carlos Tavares Carvalho (Federal University of Amapá, UNIFAP). A specimen was deposited in the UNIFAP herbarium, under code number 00258. Crude ethanolic extract of the dried leaves was obtained by percolation (Basile et al. 1990), and the material was cold crunched, after immersion in a $75 \%$ hydroalcoholic solution for $15 \mathrm{~d}$. The product was concentrated, vaporized at high pressure and lyophilized.

\section{Animals and assay procedures}

Experiments were carried out on six-week-old Wistar rats (Rattus norvegicus), weighing approximately $100 \mathrm{~g}$, and 12-week old Swiss mice (Mus musculus), weighing 25-30 g. The animals were acquired from the animal house of the Jose do Rosario Vellano University (UNIFENAS), and kept in polyethylene boxes $(n=6)$, in a climate-controlled environment $\left(25 \pm 4^{\circ} \mathrm{C}, 55 \pm 5 \%\right.$ humidity) with a $12 \mathrm{~h}$, light/dark cycle (7 a.m. to 7 p.m.). Food (LABINA-PURINA) and water were available ad libitum. The rats and mice were divided into experimental groups of 6 animals, 3 females and 3 males each. Casearia sylvestris extract was suspended in distilled water and administered in a single dose of $0.5 \mathrm{ml}$ by gavage at concentrations of 150,300 and $500 \mathrm{mg} \mathrm{kg}^{-1}$ body weight. The selected doses were based on the suggested guidelines for in vivo cytogenetic assay (Preston et al. 1987, Tice et al. 1994). To determine the highest dose of the extract, toxicity studies were conducted over a $15 \mathrm{~d}$ period. The negative control groups (both mice and rats) received distilled water. The positive control group of Swiss mice and Wistar rats received $50 \mathrm{mg}$ of N-nitroso-N-ethylurea/kg (ENU, CAS No. 759-73-9). For the micronucleus (MN) and chromosomal aberration (CA) assays on Wistar rats cells, the animals were sacrificed $24 \mathrm{~h}$ after treatment, and the bone marrow cells from both femurs were prepared, as recommended by Schmid (1976), and Ford and Hamerton (1956), respectively. One hundred metaphases per animal (600 metaphases per group) were analyzed, to determine the number of CAs in a blind test. Chromosomal aberrations were classified according to Savage (1976) as gaps, breaks, deletions, fragments, rings and dicentric chromosomes. Since the cytogenetic significance of the gaps is still not well-established, the statistical analyses were carried out excluding gaps. The mitotic index (MI) was obtained by counting the number of mitotic cells in the 1000 cells analyzed per animal. For the MN assay on Swiss mice was used the protocol recommended by MacGregor et al. (1980). Peripheral blood was collected from the orbital vein, 48 and $72 \mathrm{~h}$ after treatment, then blood smear slides were prepared. All the slides were coded, fixed with methanol and stained with Giemsa solution (Synth-G1003.08.AB). To determine the presence of the MN 2000 polychromatic erythrocytes from each Wistar rat and 4000 erythrocytes from each Swiss mouse were scored (2000 cells from a $48 \mathrm{~h}$ blood sample and 2000 cells from a $72 \mathrm{~h}$ blood sample). One thousand cells were analyzed per Swiss mouse to determine the polychromatic/normochromatic erythrocytes ratio. The Animal Bioethical Committee of the UNIFENAS, Brazil, approved the present study on July 20, 2005 (protocol number 08A/2005), in accordance with the Federal Government legislation on animal care. 

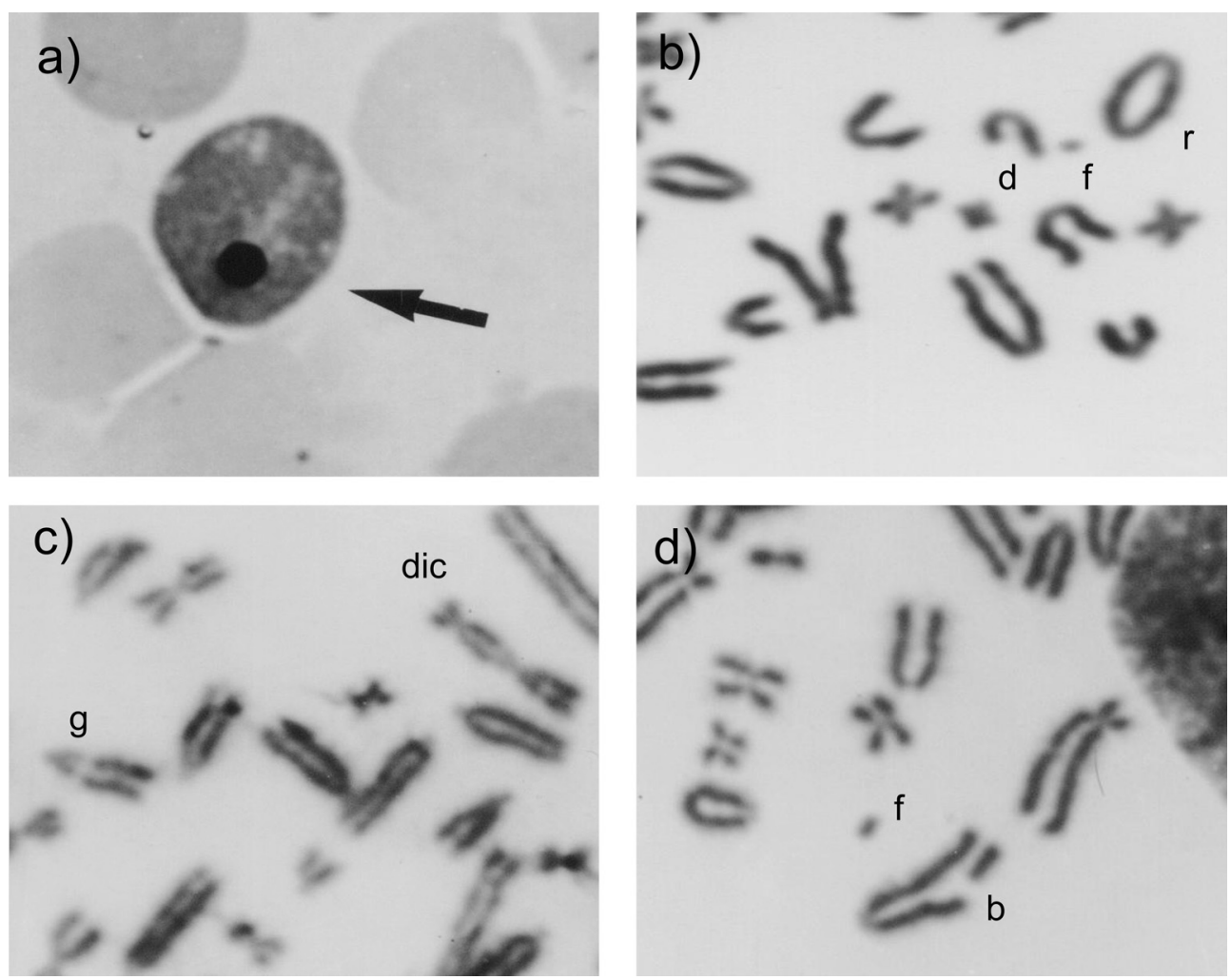

Fig. 1. Some typical chromosome aberrations on bone marrow cells of Wistar rats after N-nitroso-n-ethylurea (ENU) treatment. a) Micronucleus on polychromatic erythrocyte (arrow); b) $d=$ deletion, $\mathrm{f}=$ fragment, $\mathrm{r}=$ ring; c) $\mathrm{g}=$ isochromatidic gap, dic $=$ dicentric; d) $\mathrm{f}=$ fragment, $\mathrm{b}=$ chromatidic break.

\section{Statistical Analysis}

To verify if the data were normally distributed the data obtained on CAs and MN assays were submitted to One-way analysis of variance test (ANOVA) and the Tukey-Kramer multiple comparison test (Sokal and Rohlf 1995), using the GraphPad Instat ${ }^{\circledR}$ software (version 3.01). The results were considered statistically significant at $p<0.05$.

\section{Results and discussion}

In this study, the animals were submitted to acute treatment, via gavage, of the crude ethanolic extract of dried leaves. This treatment regimen and the administration method were considered the most suitable because they were closer to the form that treatments are conducted and some Casearia sylvestris products are ingested by the population.

Table 1 shows data on the induction of chromosome aberrations (CAs) in the division of bone marrow cells of Wistar rats, following in vivo exposure to different doses of $C$. sylvestris extract. The table shows the Mitotic Index (MI), the number of different types of CAs, and mean CAs/treatment (excluding gaps), for a total of 600 metaphases per dose.

The MI values obtained from the analysis of 1000 cells/animal for a sample of 30 animals ( $n=6 /$ group) ranged from 1.4 to $3.7 \%$ (means) and statistical analysis by the Tukey-Kramer test showed a significant decrease in MI values $(p<0.01$ and $p<0.001)$ between the 3 treatments with $C$. sylvestris extract and the negative control group. These data indicate some cytotoxic effect of the $C$. 
Table 1. Mitotic Index (MI) and distribution of the different types of chromosomal aberrations (CAs) observed in female (F) and male (M) Wistar rat bone marrow cells treated with a Casearia sylvestris extract, and respective controls. One hundred cells were analyzed per animal, with a total of 600 cells per treatment. C, Chromatid-type; IC, isochromatid-type; OA, other aberrations: del=deletion, $\mathrm{r}=$ ring; $\mathrm{SDM}=$ standard deviation of the mean

\begin{tabular}{|c|c|c|c|c|c|c|c|c|}
\hline \multirow{3}{*}{ Treatments } & \multirow{3}{*}{ Animal } & \multirow{3}{*}{$\mathrm{MI}(\%) \mathrm{OA}$} & \multicolumn{5}{|c|}{ Chromosomal aberrations } & \multirow{3}{*}{$\begin{array}{c}\text { Total (CAs) } \\
\text { without gaps }\end{array}$} \\
\hline & & & \multicolumn{2}{|c|}{ Gaps } & \multicolumn{2}{|c|}{ Breaks } & \multirow[b]{2}{*}{$\mathrm{OA}$} & \\
\hline & & & $\mathrm{C}$ & IC & $\mathrm{C}$ & IC & & \\
\hline \multirow[t]{7}{*}{ Control (Water) } & $\mathrm{F}_{1}$ & 5.4 & 1 & 1 & 1 & 0 & 0 & 1 \\
\hline & $\mathrm{F}_{2}$ & 4.3 & 1 & 0 & 1 & 0 & 0 & 1 \\
\hline & $\mathrm{F}_{3}$ & 4.4 & 0 & 0 & 2 & 0 & 0 & 2 \\
\hline & $\mathrm{M}_{1}$ & 4.8 & 1 & 0 & 1 & 0 & 0 & 1 \\
\hline & $\mathrm{M}_{2}$ & 4.0 & 2 & 1 & 3 & 0 & $1 \mathrm{del}$ & 4 \\
\hline & $\mathrm{M}_{3}$ & 3.9 & 0 & 1 & 1 & 0 & 0 & 1 \\
\hline & mean $\pm \mathrm{SDM}$ & $4.4 \pm 0.55$ & & & & & & $1.66 \pm 1.21$ \\
\hline \multirow{7}{*}{$\begin{array}{l}\text { C. sylvestris } \\
\qquad(150 \mathrm{mg} / \mathrm{kg})\end{array}$} & $\mathrm{F}_{1}$ & 1.9 & 0 & 0 & 2 & 0 & 0 & 2 \\
\hline & $\mathrm{F}_{2}$ & 3.7 & 0 & 0 & 0 & 0 & $1 \mathrm{del} / 2 \mathrm{r}$ & 3 \\
\hline & $\mathrm{F}_{3}$ & 1.4 & 0 & 0 & 0 & 0 & 0 & 0 \\
\hline & $\mathrm{M}_{1}$ & 2.4 & 1 & 0 & 0 & 0 & 0 & 0 \\
\hline & $\mathrm{M}_{2}$ & 1.7 & 3 & 0 & 0 & 0 & $2 \mathrm{del}$ & 2 \\
\hline & $\mathrm{M}_{3}$ & 1.8 & 1 & 0 & 0 & 0 & 0 & 0 \\
\hline & mean $\pm \mathrm{SDM}$ & $2.1 * * \pm 0.8$ & & & & & & $1.16 \pm 1.32$ \\
\hline \multirow{7}{*}{$\begin{array}{l}\text { C. sylvestris } \\
\qquad(300 \mathrm{mg} / \mathrm{kg})\end{array}$} & $\mathrm{F}_{1}$ & 3.3 & 2 & 0 & 3 & 0 & $1 \mathrm{r}$ & 4 \\
\hline & $\mathrm{F}_{2}$ & 2.4 & 0 & 0 & 1 & 0 & 0 & 1 \\
\hline & $\mathrm{F}_{3}$ & 3.1 & 1 & 0 & 1 & 0 & 0 & 1 \\
\hline & $\mathrm{M}_{1}$ & 3.4 & 0 & 0 & 0 & 0 & 0 & 0 \\
\hline & $\mathrm{M}_{2}$ & 3.2 & 0 & 0 & 1 & 0 & 0 & 1 \\
\hline & $\mathrm{M}_{3}$ & 2.7 & 2 & 1 & 0 & 0 & 0 & 0 \\
\hline & mean $\pm \mathrm{SDM}$ & $3.0 * \pm 0.38$ & & & & & & $1.16 \pm 1.47$ \\
\hline \multirow{7}{*}{$\begin{array}{l}\text { C. sylvestris } \\
\quad(500 \mathrm{mg} / \mathrm{kg})\end{array}$} & $\mathrm{F}_{1}$ & 1.5 & 1 & 0 & 0 & 0 & $1 \mathrm{del}$ & 1 \\
\hline & $\mathrm{F}_{2}$ & 2.1 & 0 & 0 & 1 & 0 & 0 & 1 \\
\hline & $\mathrm{F}_{3}$ & 1.7 & 0 & 1 & 0 & 0 & 0 & 0 \\
\hline & $\mathrm{M}_{1}$ & 3.6 & 0 & 0 & 1 & 0 & $2 \mathrm{del} / 1 \mathrm{r}$ & 4 \\
\hline & $\mathrm{M}_{2}$ & 1.7 & 0 & 0 & 0 & 0 & $1 \mathrm{del} / 1 \mathrm{r}$ & 2 \\
\hline & $\mathrm{M}_{3}$ & 1.6 & 1 & 0 & 1 & 0 & 0 & 1 \\
\hline & mean $\pm \mathrm{SDM}$ & $2.0 * * \pm 0.7$ & & & & & & $1.50 \pm 1.37$ \\
\hline \multirow{7}{*}{$\begin{array}{l}\text { N-nitroso-n-ethylurea } \\
\quad(50 \mathrm{mg} / \mathrm{kg})\end{array}$} & $\mathrm{F}_{1}$ & 5.0 & 2 & 1 & 2 & 1 & 0 & 3 \\
\hline & $\mathrm{F}_{2}$ & 4.6 & 1 & 0 & 4 & 0 & $1 \mathrm{del}$ & 5 \\
\hline & $\mathrm{F}_{3}$ & 4.1 & 2 & 1 & 4 & 4 & 0 & 8 \\
\hline & $\mathrm{M}_{1}$ & 5.5 & 1 & 1 & 2 & 2 & $1 \mathrm{r}$ & 5 \\
\hline & $\mathrm{M}_{2}$ & 4.1 & 1 & 2 & 2 & 1 & $1 \mathrm{de}$ & 4 \\
\hline & $\mathrm{M}_{3}$ & 3.4 & 2 & 2 & 3 & 1 & $1 \mathrm{del} / 1 \mathrm{r}$ & 6 \\
\hline & mean $\pm \mathrm{SDM}$ & $4.4 \pm 0.74$ & & & & & & $5.16^{*} \pm 1.72$ \\
\hline
\end{tabular}

* Significantly different from negative control $(p<0.01)$.

** Significantly different from negative control $(p<0.001)$.

sylvestris extract at the tested doses (Table 1).

The data obtained from 600 metaphases analysed per treatment (100 metaphase cells/animal), showed that there were no statistically significant differences between the mean number of CA of treated groups and the negative control. The most frequent types of aberrations of the treated groups were chromatid gaps, chromatid breaks and deletions.

Stastistical analysis of MN assay results (Table 2) revealed no significant difference between the average number of micronucleated cells in Wistar group rats treated with the three extract doses 
Table 2. Polychromatic erythrocytes with micronuclei (MNPCE) observed in bone marrow cells of female (F) and male (M) Wistar rats treated with Casearia sylvestris extract, and respective controls. Two thousand cells were analyzed per animal, with a total of 12000 cells per group. SDM=standard deviation of the mean.

\begin{tabular}{|c|c|c|c|c|c|c|c|c|}
\hline \multirow{2}{*}{ Treatments } & \multirow{2}{*}{$\begin{array}{l}\text { Dose } \\
\mathrm{mg} / \mathrm{kg}\end{array}$} & \multicolumn{6}{|c|}{ Number of MNPCE per animal } & \multirow{2}{*}{$\begin{array}{c}\text { MNPCE } \\
(\text { Mean } \pm \text { SDM })\end{array}$} \\
\hline & & $\mathrm{F}_{1}$ & $\mathrm{~F}_{2}$ & $\mathrm{~F}_{3}$ & $\mathrm{M}_{1}$ & $\mathrm{M}_{2}$ & $\mathrm{M}_{3}$ & \\
\hline Control (Water) & 0 & 2 & 1 & 3 & 0 & 1 & 2 & $1.50 \pm 1.04$ \\
\hline C. sylvestris extract & 150 & 2 & 4 & 4 & 1 & 1 & 2 & $2.33 \pm 1.36$ \\
\hline C. sylvestris extract & 300 & 1 & 2 & 1 & 2 & 1 & 1 & $1.33 \pm 0.51$ \\
\hline C. sylvestris extract & 500 & 1 & 4 & 4 & 1 & 1 & 3 & $2.33 \pm 1.50$ \\
\hline $\begin{array}{l}\text { Positive control } \\
\text { (N-nitroso-n-ethylurea) }\end{array}$ & 50 & 6 & 9 & 9 & 8 & 9 & 13 & $9.0 * \pm 2.28$ \\
\hline
\end{tabular}

* Significantly different from negative control $(p<0.001)$.

Table 3. Polychromatic erythrocytes with micronuclei (MNPCE) observed in peripheral blood of female (F) and male (M) Swiss mice treated with a Casearia sylvestris extract, and respective controls. Two thousand cells were analyzed per animal, for a total of 12000 cells per group. PCE $=$ Polychromatic erythrocytes; $\mathrm{NCE}=$ Normochromatic erythrocytes; SDM=standard deviation of the mean.

\begin{tabular}{|c|c|c|c|c|c|c|c|c|c|}
\hline \multirow{2}{*}{ Treatments } & \multirow{2}{*}{$\begin{array}{c}\text { Blood } \\
\text { collect time }\end{array}$} & \multicolumn{6}{|c|}{ Number of MNPCE per animal } & \multirow{2}{*}{$\begin{array}{c}\text { MNPCE } \\
(\text { Mean } \pm \text { SDM) }\end{array}$} & \multirow{2}{*}{$\begin{array}{c}\mathrm{PCE} / \mathrm{NCE} \\
(\mathrm{Mean} \pm \mathrm{SDM})\end{array}$} \\
\hline & & $\mathrm{F}_{1}$ & $\mathrm{~F}_{2}$ & $\mathrm{~F}_{3}$ & $\mathrm{M}_{4}$ & $\mathrm{M}_{5}$ & $\mathrm{M}_{6}$ & & \\
\hline Control & $48 \mathrm{~h}$ & 4 & 5 & 4 & 5 & 4 & 6 & $4.66 \pm 0.81$ & $1.15 \pm 0.10$ \\
\hline (Water) & $72 \mathrm{~h}$ & 5 & 6 & 4 & 4 & 6 & 5 & $5.0 \pm 0.89$ & $1.14 \pm 0.05$ \\
\hline C. sylvestris & $48 \mathrm{~h}$ & 6 & 5 & 3 & 6 & 5 & 5 & $5.0 \pm 1.09$ & $3.79 * * \pm 2.26$ \\
\hline$(150 \mathrm{mg} / \mathrm{kg})$ & $72 \mathrm{~h}$ & 6 & 7 & 6 & 3 & 5 & 4 & $5.16 \pm 1.47$ & $2.65^{* *} \pm 1.31$ \\
\hline C. sylvestris & $48 \mathrm{~h}$ & 6 & 6 & 6 & 5 & 2 & 6 & $5.16 \pm 1.60$ & $2.12 \pm 0.53$ \\
\hline$(300 \mathrm{mg} / \mathrm{kg})$ & $72 \mathrm{~h}$ & 6 & 5 & 5 & 6 & 6 & 5 & $5.50 \pm 0.54$ & $2.94 \pm 2.76$ \\
\hline C. sylvestris & $48 \mathrm{~h}$ & 3 & 5 & 5 & 7 & 3 & 5 & $4.66 \pm 1.50$ & $2.12 \pm 0.72$ \\
\hline$(500 \mathrm{mg} / \mathrm{kg})$ & $72 \mathrm{~h}$ & 5 & 7 & 7 & 6 & 6 & 6 & $6.16 \pm 0.75$ & $1.73 \pm 0.42$ \\
\hline (N-nitroso-n-ethylurea) & $48 \mathrm{~h}$ & 9 & 13 & 12 & 14 & 11 & 14 & $12.16^{*} \pm 1.94$ & $1.92 \pm 0.61$ \\
\hline$(50 \mathrm{mg} / \mathrm{kg})$ & $72 \mathrm{~h}$ & 10 & 15 & 10 & 11 & 13 & 12 & $11.83 * \pm 1.94$ & $1.64 \pm 0.20$ \\
\hline
\end{tabular}

* Significantly different from negative control $(p<0.001)$.

** Significantly different from negative control $(p<0.05)$.

and those that received distilled water $(p<0.05)$, indicating, as also observed in the CA assay, that acute administration of the crude ethanol extract of the leaves of $C$. sylvestris is not clastogenic in Wistar rats.

Table 3 summarizes the results of the analysis of MN in peripheral blood of Swiss mice, following treatment with different concentrations of $C$. sylvestris extract and controls. Administration of the extract also did not result in an increase in the average number of polychromatic erythrocytes with micronuclei (MNPCE) in the peripheral blood cells of Swiss mice, in either of the cell samples analysed (48 and $72 \mathrm{~h}$ after the treatment). Comparisons between different dose groups showed no significant differences between MNPCE mean numbers (Tukey-Kramer test, $p>0.05$ ). In relation to normochromatic erythrocytes (NCE), for the ratio between the mean number of polychromatic erythrocytes (PCE), an alteration was detected only with the $150 \mathrm{mg} \mathrm{kg}^{-1}$ dose, suggesting an increased rate of erythropoiesis. This result disagrees with that obtained for bone marrow cells of 
Wistar rats, in which a small but significant decrease in the mitotic index was observed at 3 tested doses. On the other hand, the fact that toxicity can often followed by compensatory cell division must be considered.

The results obtained in the cells of Wistar rats and mice in the present study agree with those of Maistro et al. (2004), who observed after in vitro analysis on Hepatoma Tissue Culture (HTC cells) of Rattus norvegicus and Chinese hamster V79 cells, no genotoxic effects using the same $C$. sylvestris extract.

The phytochemical characterization of the leaf extract from Casearia sylvestris mainly revealed the presence of triterpenes, diterpenes, coumarins, tannins, some volatile oils, flavonoids (Sertié et al. 2000), the major components being a source of casearins (clerodane diterpenes: casearin G, S and T) (Carvalho et al. 1998) and casearvestrins A, B and C (Oberlies et al. 2002), in association with minerals $\mathrm{Ca}, \mathrm{K}, \mathrm{Mg}, \mathrm{Br}, \mathrm{Cl}, \mathrm{Fe}, \mathrm{Mn}, \mathrm{Na}, \mathrm{Rb}$ and $\mathrm{Zn}$ at the $\mu \mathrm{g} \mathrm{g}^{-1}$ levels and $\mathrm{Co}, \mathrm{Cr}$, $\mathrm{Cs}, \mathrm{La}$, and Sc at the $\mu \mathrm{g} \mathrm{kg}^{-1}$ levels (Yamashita et al. 2005). The results obtained by Maistro et al. (2004), and by ourselves in the present study, show that these mixed compounds in the extract have no genotoxic effects on HTC and V79 cells in vitro, and no clastogenic/aneugenic action on bone marrow and peripheral blood cells of Rattus norvegicus and Mus musculus in vivo. However, some caution is needed with the routine use of the C. sylvestris leaf extract, until the mitotic index decrease effect observed in our study can be better investigated.

\section{Acknowledgments}

We would like to thank the Brazilian agencies CNPq (306544/2006-7), FAPESP (2006/575142) and FAPEMIG (Rede Mineira de Ensaios Toxicológicos e Farmacológicos de Produtos Terapêticos, EDT-1879/02) for their financial support for this study, and Lucimara Maria da Silva for her technical assistance.

\section{References}

Basile, A. C, Sertié, J. A. A., Panizza, S., Oshiro, T. T. and Azzolini, C. A. 1990. Pharmacological assay of Casearia sylvestris. In: Preventive antiulcer activity and toxicity of the leaf crude extract. J. Ethnopharmacol. 30: 85-197.

Carvalho, P. R. F., Furlan, M., Young, M. C. M., Kingston, D. G. I. and Bolzani, V. S. 1998. Acetylated DNA-damaging clerodane diterpenes from Casearia sylvestris. Phytochemistry 49: 1659-1662.

Esteves, I., Souza, I. R., Rodrigues, M., Cardoso, L. G. V., Santos, L. S., Sertie, J. A. A., Perazzo, F. F., Lima, L. M., Schneedorf, J. M., Bastos, J. K. and Carvalho, J. C. T. 2005. Gastric antiulcer and anti-inflammatory activities of the essential oil from Casearia sylvestris Sw. J. Ethnopharmacol. 101: 191-196.

Ford, C. E. and Hamerton, J. L. 1956. A colchicine, hypotonic citrate, squash sequence for mammalian chromosomes. Stain Technol. 31: 247-251.

Hoehme, F. C. 1939. Planta e substâncias vegetais tóxicas e medicinais. Graphics, São Paulo, Brasil, pp. 196-199.

Le Cointe 1947. Amazônia Brasileira. Árvores e plantas úteis. Vol. 3. Ed. Nacional, São Paulo, Brasil, p. 433.

Lorenzi, H. and Matos, F. J. A. 2002. Plantas Medicinais no Brasil. In: Nativas e Exóticas, first ed. Instituto Plantarum de Estudos da Flora Ltda, Nova Odessa, S. Paulo, pp. 220-221.

MacGregor, J. T., Wehr, C. M. and Gould, D. H. 1980. Clastogen-induced micronuclei in peripheral blood erythrocytes: the basis of an improved micronucleus test. Environmental Mutagenesis 2: 509-514.

Maistro, E. L., Carvalho, J. C. T. and Mantovani, M. S. 2004. Evaluation of the genotoxic potential of the Casearia sylvestris extract on HTC and V79 cells by the comet assay. Toxicology In Vitro 18: 337-342.

Oberlies, N. H., Burgess, J. P., Navarro, H. A., Pinos, R. E., Fairchild, C. R., Peterson, R. W., Soejarto, D. D., Farnsworth, N. R., Kinghorn, A. D., Wani, M. C. and Wall, M. E. 2002. Novel bioactive clerodane diterpenoids from the leaves and twigs of Casearia sylvestris. J. Nat. Prod. 65: 95-99.

Preston, R. J., Dean, B. D., Gallow, S., Holden, H. E., Macfee, A. F. and Shelby, M. 1987. Mammalian in vivo cytogenetic assay analysis of chromosomal aberration in bone marrow cells. Mutat. Res. 189: 157-165.

Savage, J. R. K. 1976. Classification and relationships of induced chromosomal structural changes. J. Med. Genet. 13: $103-122$.

Schmid, W. 1976. The micronucleous test for cytogenetic analysis. In: Chemical Mutagenesis, Principles and Methods for 
their Detection (Hollaender, A., ed.). Vol. 4. Plenum Press, New York, pp. 31-53.

Sertié, J. A. A., Carvalho, J. C. T. and Panizza, S. 2000. Antiulcer activity of the crude extract from the leaves of Casearia sylvestris. Pharmaceutical Biology 38: 112-119.

Sokal, R. R. and Rohlf, F. J. 1995. In: W. H. Freeman (Ed.), Biometry. San Francisco, pp. 175-205; 404-486.

Surh, Y. and Ferguson, L. R. 2003. Dietary and medicinal antimutagens and anticarcinogens: molecular mechanisms and chemopreventive potential-highlights of a symposium. Mutat. Res. 523-524: 1-8.

Tice, R. R., Hayashi, J. T., MacGregor, J. T., Anderson, D., Blakey, D. H., Holden, H. E., Kirsch-Volders, M., Oleson-Jr, F. B., Pacchierotti, F., Preston, R. J., Romagna, F., Shimada, H., Sutou, S. and Vanier, B. 1994. Report from the working group on the in vivo mammalian bone marrow chromosomal aberration test. Mutat. Res. 312: 303-312.

Yamashita, C. I., Saiki, M., Vasconcellos, M. B. A. and Sertié, J. A. A. 2005. Characterization of trace elements in Casearia medicinal plant by neutron activation analysis. Applied Radiation and Isotopes 63: 841-846. 